\title{
Biomechanical and Thermographic Analysis in the Transtibial Prosthesis Socket - Stump Interface
}

\author{
Jozef Živčák*, Radovan Hudák,Viktória Rajtúková
}

Technical university in Košice, Faculty of Mechanical Engineering, Department of Biomedical Engineering and measurement, Letná 9, 042 Košice

\begin{abstract}
The study deals with the problem of a biomechanical solution for human locomotion after amputation of a lower limb. With unsuitably designed sockets for transtibial prostheses interaction between the socket and the stump occurs, leading to increased friction and subsequent surface damage to the soft tissue. This damage is manifested in local increases in the temperature of the affected area. With individual types of transtibial prostheses, sites which can be loaded and which cannot be loaded are defined. On the basis of a study of the anterior side of the stump three loadable and two non-loadable areas were monitored using a thermal imaging camera and a pressure sensor. Methods of measuring individual values were proposed for the purpose of sensing temperature and pressure. For sensing the surface temperature of the selected areas on the stump a thermal imaging FLIR SC-660 camera (Wilsonville, Oregon, USA) was used. The working of pressure on the sockets of transtibial prostheses were sensed using a Tactilus pressure sensor from the company Sensor Products Inc. (Madison, New Jersey, USA). In the submitted work 11 stumps were non-invasively monitored without interrupting the integrity of the skin. On the basis of the proposed method of assessing the distribution of temperature it was determined that in the case of a suitably made prosthesis no significant change of temperature occurs in any of the monitored areas. The results obtained by the temperature and pressure measurement were statistically processed.
\end{abstract}

Keywords: Pressure sensor, transtibial prostheses, medical thermography, methodology.

\section{Introduction}

Despite the modern technologies used during the production of prostheses, interaction still occurs between a prosthesis and a stump, which as a consequence causes pain, damage to soft tissue on the stump and even complete rejection of the prosthesis being used. The mentioned consequence can occur during interaction of the socket-stump, which is one of the most important factors for assessing correction, support or fixation of a biomechanical effect. At present the demand has arisen for a system capable of measuring pressure between the stump and the socket without interrupting the integrity of the prosthesis socket. Using a pressure sensor it would be possible to sense the working of pressure on the stump and thus optimize the prosthesis socket. A thermal imaging camera, which is at present beginning to be used as an auxiliary diagnostic method in medical thermography, could be used as a supplementary measuring method for determining an incorrectly rigged prosthesis or incorrectly made socket. 
A transtibial prosthesis is defined as an artificial replacement of the lower limb after a below-knee amputation. It represents the replacement of the lost function of the ankle joint and the foot, which is important for smooth and natural walking. A transtibial prosthesis represents a complete element which is always adapted to the given user [1]. The number of transtibial prostheses in Slovakia is according to [2] approximately 300 units per year.

Measuring the temperature on the surface of the human body is one of the oldest methods of diagnosis. This value depends on the individual physiological characteristics of the organism but is determined by pathological changes in the organism. Measuring it means obtaining the possibility of discovering and determining these pathological changes in more detail [3]. The reactions of the stump's tissue to the working of external forces are complex; they include tissue deformation, interstitial streaming, ischemia, hyperemia, perspiration, pain, a change of skin temperature, a change in skin colour, etc. Mechanical forces working on the surface of the stump's skin cause straining and stress in the skin and tissues of the stump. [4]

In Figure 1 the temperature of the individual areas of the body on the anterior part of the human body is shown according to the study by Ivanitsky [5] and Lee [6]. In the presented study the temperature in the below-knee area was measured, and according to the mentioned studies the surface temperature should be approximately $31^{\circ} \mathrm{C}$.

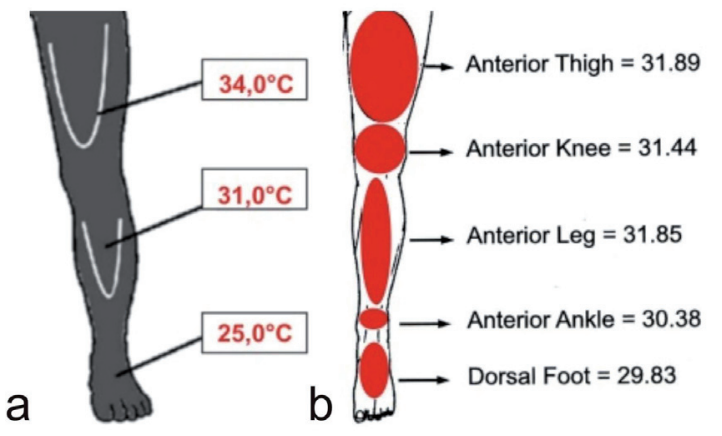

Fig. 1: Temperature of the blood in the human body and the surface temperature of the human body according to the study of a) Ivanitsky [5] and b) Lee [6].

Kristen et al. [7] performed a quantitative study in which a thermal imaging camera was used for determining phantom pain after amputation. They determined an asymmetrical rise in the temperature localized in the areas of the stump in which infection or pain were located or a site causing greater pressure. It was further determined that phantom pains associated with thermal maps. A lowering of the temperature was observed from the proximal to the distal part of the stump in al cases. Another use of a thermal imaging camera for tracking temperature changes on a stump can be for supplementing a thermal map, together with information about the humidity within the socket during walking.

In the study [8] Cutti et al. dealt with application of a thermal imaging camera as a technology which can help with targeted modifications of the socket of a prosthesis, comparing the impact of different types of liners on the stump and the possibility of contributing to increased comfort of the user. The study was focused on monitoring temperature changes with a transtibial amputation before and after walking while wearing the prosthesis. The user with the transtibial prosthesis walked for 15 minutes, during which time an average rise in temperature of $20 \%$ was found. At possible critical sites $80 \%$ of the mentioned subjects had a raised temperature in the lower area of the kneecap and on the medial side of the femur head and $40 \%$ showed an increased temperature on the anterior edge of the tibia and on the lateral side of the femur head.

Thermal imaging can be used during clinical decisions on setting the construction of the socket, on localization of phantom pain as a supporting diagnostic during analgesic treatment, on localization of inflammation processes discovered on a stump, on localization of thrombotic symptoms after amputation with diseases of the peripheral blood vessels, for the purpose of checking the state of the stump before and after use of the transtibial prosthesis. At present no studies are available which have been devoted to the use of a thermal imaging camera in a prosthetic for measuring the temperature of stumps.

Distribution of pressure on the interface between the stump and the transtibial prosthesis socket is required for the assessment of the socket design and construction. The measuring of pressure in transtibial prosthesis sockets has been carried out for almost 50 years. Acquisition of correct data by 
such pressure measurements in sockets requires proper measuring technology, appropriate sensors and proper sensor positioning and data collection. An ideal pressure sensor should facilitate the monitoring of the actual surface tension, i.e. the pressure distribution, without substantial interventions in the initial conditions of the socket structure. At present, this is usually carried out using Matrix TACTILE Sensors (MTS), the application of which has become significant in the healthcare sector as well as in the prosthetics and orthotics sectors [9].

In his study, Faustini [11] carried out pressure measurements after transtibial amputation using the F-Socket 9811 (Tekscan) sensor (Fig. 2b). One sensor was placed on the lateral side of the stump and the fibula head, the second on the distal part of the tibia on the anterior stump side. The F-Socket sensor dimensions were $76.2 \mathrm{~mm} \times 203.2 \mathrm{~mm}$, with a thickness of $0.28 \mathrm{~mm}$, and it contained 96 sensors (each with an area of $161.3 \mathrm{~mm}^{2}$ ), arranged into 6 columns and 16 rows, with a pressure range between 0 and $517 \mathrm{kPa}$. In their study, Dumbletonet al. [12] dealt with a comparison of the dynamic pressure interface between the socket and the transtibial stump. The pressure measurements in the endoskeletal prosthesis were carried out using a Tekscan F-scan pressure scanner (Tekscan, Inc; Boston, Massachusetts, USA). Scanning in the prosthesis socket was carried out on the anterior, medial, posterior and lateral sides. It was observed that the distribution of the dynamic pressure on the stump interface was similar on both the loadable and unloadable areas.

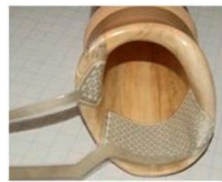

a

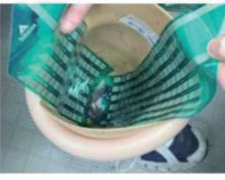

b

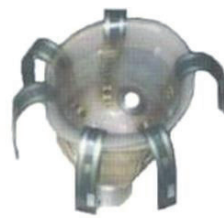

C
Fig. 2: Types of sensors a) Novel GmbH (Germany), b) Tekscan FSocket (Boston), c) Socket Rincoe.

In their study, Kang et al. [13] examined the effects of various settings of the transtibial prosthesis socket $\left(5^{\circ}, 0^{\circ}, 10^{\circ}\right)$ using the F-socket pressure system (Tekscan). They measured the effects of pressure in the anterior area (proximal, medial and distal) and the posterior area (proximal, medial and distal) at different socket flexion angles $\left(5^{\circ}, 0^{\circ}\right.$ and $10^{\circ}$ ). The pairwise t-test was used to compare the pressure in a socket with the flexion angle of $5^{\circ}$ and the pressures in the socket flexion angles of $0^{\circ}$ and $10^{\circ}$, while the significant level was 0.05 . In other studies, the pressure system was used for measuring pressure in the transtibial prosthesis socket during walking [14][15] and during walking up stairs [16][17][18].

\section{Materials and Methods}

On the basis of pilot measurements a method for measuring the temperature using a thermal imaging camera and pressure using a pressure sensor was prepared; this consisted of a method for preparing the room, a method for the measuring system, a method for preparing the subject, a method for processing the obtained data and creating reports and a method for evaluating and implementing the data.

During the measuring, 5 areas on the anterior side of the transtibial stump are monitored, on which the loadable areas (ON1, ON2, ON3) and unloadable areas (NON4, NON5). The selected loadable areas in the submitted study are ON1 (medial area of the tibia), ON2 (the area between the tibia and the fibula) and ON3 (quadriceps tendon). The NON4 (anterior edge of the tibia) and the NON5 (bone end of the stump) areas are sensitive to pressure, i.e. they are unloadable (Fig.3).

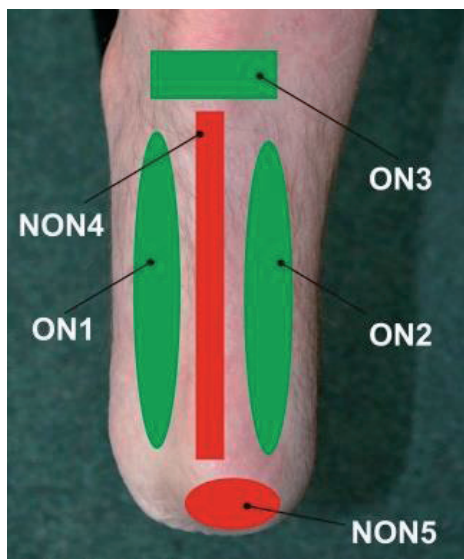

Fig. 3: Loadable areas (ON1, ON2, ON3) and unloadable areas (NON4, NON5) on the transtibial stump.

Using a FLIR SC-660 (FLIR, Wilsonville, Oregon, USA) thermal imaging camera the surface temperature of the stump was sensed in the 
selected areas. The first requirement was ensuring a consistent temperature (from $21^{\circ} \mathrm{C}$ to $24^{\circ} \mathrm{C}$ ) in the diagnostic room. A FLIR SC-660 thermal imaging camera with a spectral range $7.5-13$ $\mu \mathrm{m}$, which meets the requirements for a thermal imaging camera used for medical purposes, was used for measuring. Before the measuring itself the initial parameters, such as the temperature and humidity of the diagnostic room, the temperature range (from $-20^{\circ} \mathrm{C}$ to $+100^{\circ} \mathrm{C}$ ), the distance of the camera to the sensed subject (from $0.50 \mathrm{~m}$ to $0.80 \mathrm{~m})$, emissivity of the human body (0.98) and the selection of the colour scale, were set on the thermal imaging camera.

The thermograms obtained using the FLIR SC660 thermal imaging camera is further evaluated using the FLIR Reporter software (Fig. 4). The monitored areas on the transtibial stump, from which the necessary values are obtained, are labelled/selected using polygons.
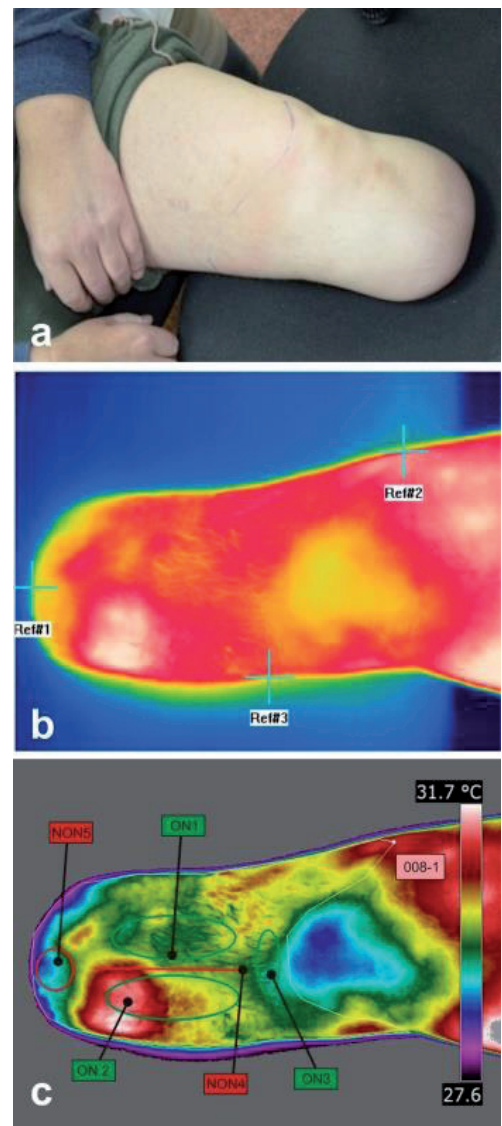

Fig. 4: Methodology of measurement by thermal imager FLIR SC660 .
The pressure measurements at the stump/liner interface and the liner/transtibial prosthesis socket interface were carried out using the TACTILUS system by SENSOR PRODUCTS INC. (USA). The TACTILUS system consists of a sensor pad $(20 \times 20 \mathrm{~cm})$ with a range of 0 to $97.19 \mathrm{kPa}$, a signal converter, a laptop with the installed TACTILUS software application and interconnecting cables.

Free movement of a subject with an applied pressure pad was secured by an interconnecting cable with a length of 10 metres between the converter and the pad. Wide cables containing 40 cores transmit signals from individual sensors $(20 \times 20 \mathrm{~cm})$ and subsequently form a matrix of 400 sensing points. The software assigns different colours, representing specific compression loads, to individual analogue signal strengths [19].

Prior to measurement, all hardware components of the TACTILUS system (pressure pad, connecting cable and converter) must be properly connected. The methodology for the pressure pad placement is identical for both measurement types. In the first case, the pressure pad is applied to the stump, the liner is slipped over, and then the prosthesis itself is applied (Fig. 5a). In the second case, the pressure pad is applied to the liner and the subject puts on the prosthesis (Fig. 5b). After the prosthesis is put on, the subject walks 8-10 metres, while the dynamic pressure development is recorded in real time. Using the software, the dynamic pressure measurement can concurrently be viewed on a laptop/PC screen, and the measurement can be repeated, if necessary. No special attachments of the TACTILUS system are required; after the liner is slipped over, the sensor's movement was hindered and sufficient securing was achieved. The same applies to the second method of prosthesis placement, where the pad stabilisation was achieved after the prosthesis was attached.

Prior to a measurement, the subject should be instructed on the measurement procedure, development and objective. During the sensor application, the subject sits on a chair to enable better access for applying the pressure pad. Prior to each measurement, a trial measurement is carried out to identify the correct position of the pressure pad by pressing the selected areas (ON1, ON2, ON3, NON4, NON5) with the fingers and checking their position using the TACTILUS software.

The submitted study monitored the values 

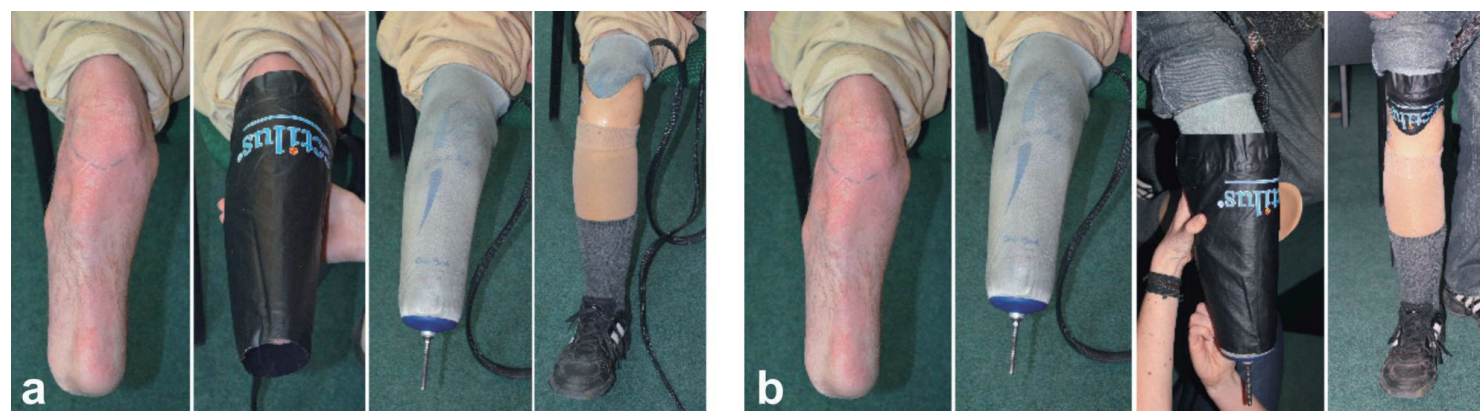

Fig. 5: Pressure sensor placement methods- a) stump/liner, b) liner/socket.

of the maximum and the average pressure for the selected areas on the transtibial stump. The selected areas (ON1, ON2, ON3, NON4 and NON5) were marked on the generated pressure matrix. Fig.6 shows the impact of pressure in the selected areas, whereas the impact of the pressure was identified for each selected area separately. The positions of the individual selected areas were identified by a trial measurement, and the trial measurement was considered in the assessment regarding the selection of the monitored areas. After the selected areas are marked, the TACTILUS software provides a graphical representation of the dynamic development of the measurement in the form of curves (Fig. 6). As various stresses affect the transtibial prosthesis socket during a walking cycle, each selected area was assessed separately. By means of a graphic curve, the maximum and the average values were identified for a particular selected area. Selection of a monitored area is followed by the visualisation of the curves of the minimum, average and maximum pressure, presented on the dynamic curve of the pressure impact for one area. Fig. 6 shows the assessed output from the TACTILUS pressure sensor with the marked selected areas. Using the TACTILUS software, the average impact of the pressure between the stump and the liner was assessed.

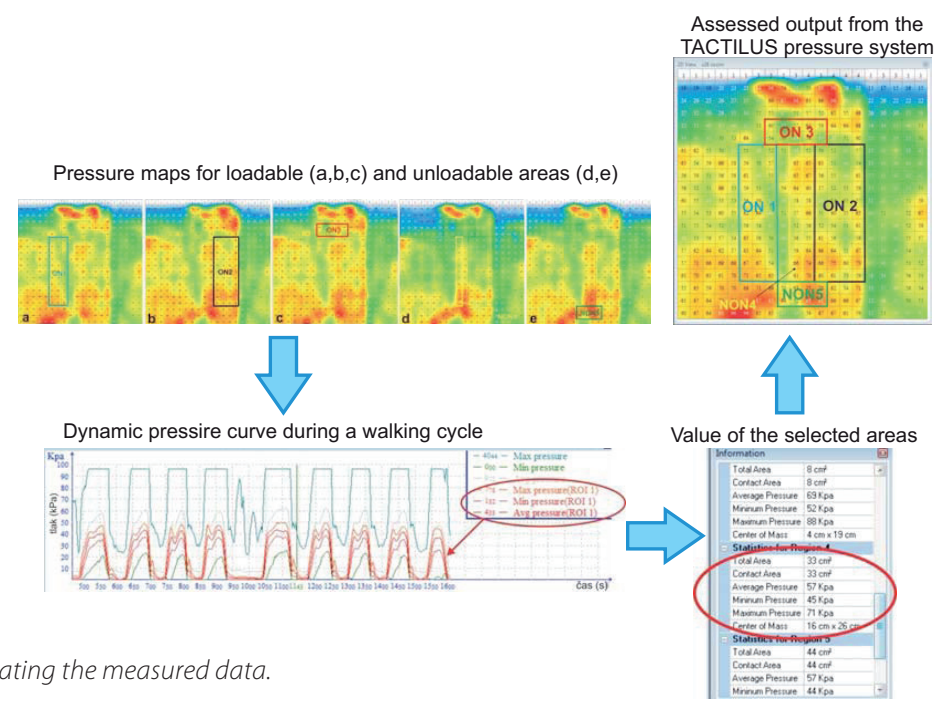

Fig. 6: Method of evaluating the measured data.

The pilot measurements were used as the basis for preparing the methodology for taking pressure measurements in the transtibial prosthesis socket at the stump/liner and liner/socket interfaces. The measurements were carried out using the FLIR SC-660 thermal imaging camera (Wilsonville,
Oregon, USA) and the TACTILUS pressure sensor (SENSOR PRODUCTS INC, USA). The methodology consisted of preparing the environment where the measurements were carried out, preparing the measuring system, preparing the subject, processing of the acquired data, elaborating reports 
and implementing the data. The measurements were carried out on 11 transtibial stumps of 10 subjects; out of these, 9 subjects had unilateral transtibial amputation and in one case a bilateral transtibial amputation. The subjects did not report any pain during the utilisation of their transtibial prosthesis; their stump soft tissue integrity was not disturbed, and they did not feel any major pressure in the socket. Except for the subject with the bilateral amputation, all the users of transtibial prostheses were active. Subjects participating in the measurements were males aged 41 to 70 years. The average age of subjects was $55.72 \pm 8.08$ years. The period of prosthesis utilisation varied (between 2 and 47 years).

Before the evaluation itself a repeatability test was conducted: the same thermogram was evaluated several times for the purpose of determining the influence of the operator on evaluation of the obtained thermograms. In the scope of the surveying the repeatability of the evaluations of the obtained thermograms the first scan was evaluated 20-times during the sensing of stump no. 8. The evaluation ran by a gradual reading and assessment of the thermogram. The arithmetic average $(X \max )$, the variation range $(V R)$, the standard deviation $\left(s_{\max }\right)$, the standard uncertainty type $\mathrm{A}\left(u_{a}\right)$ and the combined standard uncertainty type A $\left(u_{a c}\right)$ were all evaluated. The following relationship was used for the calculation:

Variation range $V R$

$$
V R=\max \left(T_{O N i}\right)-\min \left(T_{O N i}\right)
$$

Where: $\max \left(T O N_{i}\right)$ - maximum value for the area $O \mathrm{Ni}_{\mathrm{i}}$ or $\mathrm{NON}_{\mathrm{i}}$ min $\left(\mathrm{TON}_{i}\right)$ - minimum value for the area $\mathrm{ON}_{\mathrm{N}}$ or $\mathrm{NONi}$

Standard deviation Smax

$s_{\max }=\sqrt{\frac{\sum(x i-X \max )^{2}}{(n-1)}}$
Where: $x i$ - measured value, Xmax - mean, $n$ number of measurement.

Standard uncertainty type A $u_{A}$

$u_{A}=\frac{s_{\max }}{\sqrt{n}}$

Combined standard uncertainty type A $u_{A C}$

$u_{A C}=\sqrt{\sum\left(u_{A i}\right)^{2}}$

Where: $u a i$ - standard uncertainty type A

It was determined that the total uncertainty of the maximum temperature is 0.0001 and the total uncertainty of type $A$ of the average temperature is 0.023 .

During the measuring of the temperature on the surface of the stump 385 thermograms were taken and evaluated. Using equation (5) the range between the maximum temperature of the last and first thermogram in the selected areas for the given stump was obtained in order to verify whether a drop in temperature took place in the selected areas during acclimatization.

$$
R \max _{h}=T \max _{35}-T \max _{1}
$$

Where: Rmaxh - the range defined by the difference of the maximum value of the last and first thermogram for the given stump and the given area, $\operatorname{Tmax}_{35}$ - the maximum value of the temperature of the last (35th) thermogram for the given stump and the given area, $\operatorname{Tmax}_{1}$ - the maximum value of the temperature of the stump of the first thermogram for the given stump and given area.

As shown in Fig. 8, the strongest impact of the average pressure between the stump and the liner was observed in the ON1 area with a value of $81 \mathrm{kPa}$. In contrast, the lowest value of the average pressure was $21 \mathrm{kPa}$ in the NON4 area.

\begin{tabular}{|c|c|c|c|c|c|c|c|c|c|c|}
\hline Values in $\left({ }^{\circ} \mathrm{C}\right)$ & $\begin{array}{l}\text { ON1 } \\
\max \end{array}$ & avg & $\begin{array}{l}\text { ON2 } \\
\max \end{array}$ & avg & $\begin{array}{l}\text { ON3 } \\
\text { max }\end{array}$ & avg & $\begin{array}{l}\text { NON4 } \\
\text { max }\end{array}$ & avg & $\begin{array}{l}\text { NON5 } \\
\max \end{array}$ & avg \\
\hline Variation range & 0 & 0.1 & 0 & 0.1 & 0 & 0.1 & 0 & 0.1 & 0.1 & 0.1 \\
\hline Standard deviation & 0 & 0.047 & 0 & 0.02 & 0 & 0.041 & 0 & 0.051 & 0.022 & 0.041 \\
\hline Standard uncertainty type A & 0 & 0.011 & 0 & 0.011 & 0 & 0.009 & 0 & 0.011 & 0.0011 & 0.009 \\
\hline
\end{tabular}

Table 1: Maximum and average values for evaluation of repeatability. 


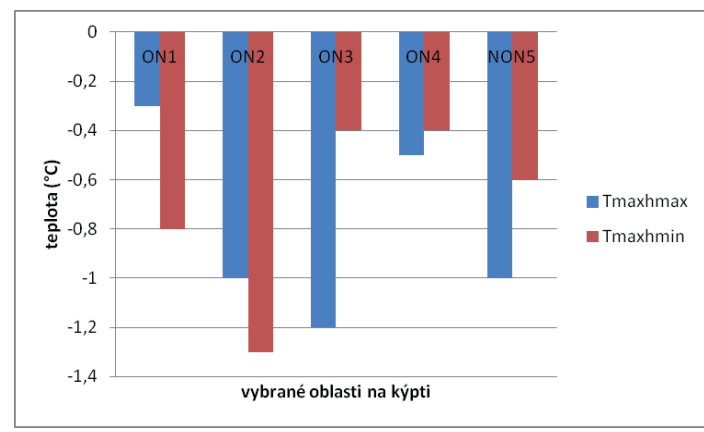

Fig. 7: Range of selected areas for Tmax35 and Tmax1.

The average value was also identified for the second method of the pressure system placement (Fig. 7). The highest value of the average pressure between the liner and the socket was $78 \mathrm{kPa}$ in the NON5 area. In this case the lowest value of the average pressure was again identified in the NON4 area with a value of $6 \mathrm{kPa}$.

The TACTILUS pressure sensor was used to identify the impact of the pressure in the selected areas (ON1, ON2, ON3, NON4, NON5), as well as the pressure distribution. In each subject, the pressure was measured at the stump/liner and liner/socket interfaces. In the case of the 007 stump, the pressure was only measured at the stump/liner interface, as the structure of this transtibial prosthesis did not allow for pressure measurement at the liner/socket interface. On the basis of the obtained results it can be stated that the liner absorbs the pressure developed in the socket when prosthesis is worn.

With respect to the fact that a dependence between temperature and pressure was anticipated, the correlation coefficients and P-values were calculated and dependence graphs of temperature to pressure were configured. Tab. 2 summarizes the individual values for the maximum temperature and maximum pressure or the measured temperature and measured pressure for the individual stumps, whereby the sensor was placed between the stump and the liner. The result is a correlation coefficient and a P-value for the individual areas.

From the results it follows that no relationship is visible between temperature and pressure in the monitored areas. The correlation coefficients for the given areas are low, and the P-value does not confirm the hypothesis regarding the mutual dependence of temperature and pressure. In the graph (Fig. 8) the aggregate of values are marked which, however, do not have common parameters. The relationship in the scope of the individual aggregates would be possible to evaluate with a higher set of values.

Table 2: Values for the correlation coefficient and the P-value (stump-liner).

\begin{tabular}{|l|l|l|l|l|}
\hline $\begin{array}{l}\text { Stump- } \\
\text { liner }\end{array}$ & $\begin{array}{l}\text { Tmax-Pmax1 } \\
\text { Correlation } \\
\text { coefficient }\end{array}$ & P-value & \multicolumn{3}{l|}{$\begin{array}{l}\text { Tavg-Pmax1 } \\
\text { Correlation } \\
\text { coefficient }\end{array}$} & P-value \\
\hline ON1 & 0.208 & 0.563 & 0.384 & 0.274 \\
\hline ON2 & 0.355 & 0.314 & 0.498 & 0.134 \\
\hline ON3 & -0.062 & 0.866 & 0.1446 & 0.688 \\
\hline
\end{tabular}
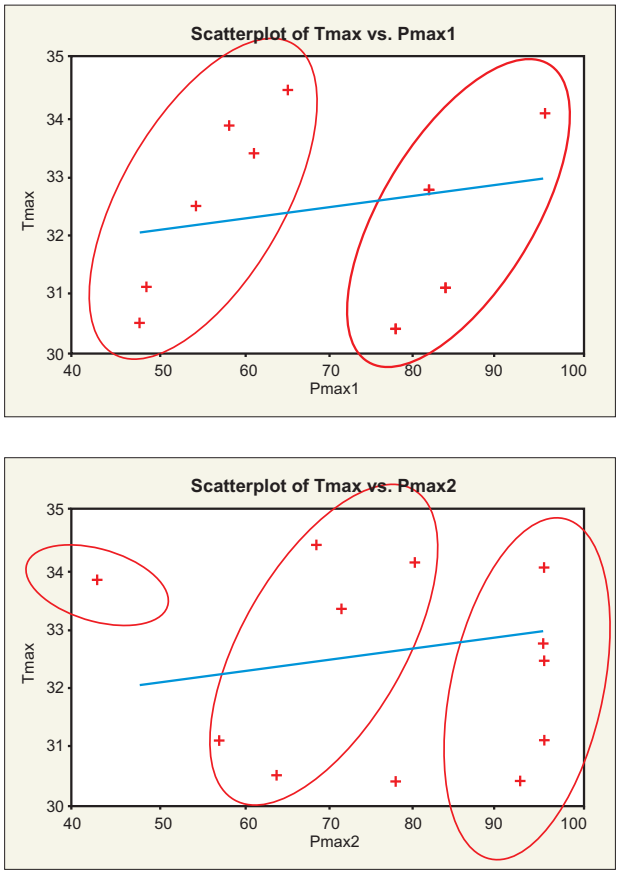

Fig. 8: Method of evaluating the measured data.

In Tab. 3 the individual values for the maximum temperature and maximum pressure or the measured temperature and measured pressure are summarized for the individual stumps, whereby the sensor was placed between the liner and the socket. The result is a correlation coefficient and a P-value for the individual areas.

The statistical significance for the maximum and average temperatures for comparing of the individual areas ON1, ON2, ON3 were evaluated using ANOVA. From the results it follows that there 
Table 3: Values for the correlation coefficient and the P-value (liner-bed).

\begin{tabular}{|c|c|c|c|c|}
\hline $\begin{array}{l}\text { Socket } \\
\text { - liner }\end{array}$ & $\begin{array}{l}\text { Tmax-Pmax } \\
\text { Correlation } \\
\text { coefficient }\end{array}$ & P-value & $\begin{array}{l}\text { Tavg-Pmax } \\
\text { Correlation } \\
\text { coefficient }\end{array}$ & P-value \\
\hline ON1 & -0.119 & 0.727 & 0.163 & 0.632 \\
\hline ON2 & -0.171 & 0.614 & -0.142 & 0.677 \\
\hline ON3 & -0.014 & 0.968 & 0.065 & 0.848 \\
\hline
\end{tabular}

is no statistically significant difference between the individual sets of data; thus, it can be stated that they correspond.

The statistical significance for the maximum and average pressures between the stump-liner and the liner-bed for comparing of the individual areas ON1, ON2, ON3 were evaluated using ANOVA. From the results it follows that there is a statistically significant difference between the individual sets of data; thus, it can be stated that they do not correspond.

\section{Conclusions}

From the evaluated results it follows that thermal imaging diagnostic and the measuring of pressure in the socket of a transtibial prosthesis are suitable methods for rapid diagnosis of a properly made socket. The mentioned systems can be used during the design, manufacture and application of the socket of the transtibial prosthesis itself. Their importance is also applied with testing and modification of the socket of transtibial prostheses. Both methods are also suitable for all types of lower-limb amputations.

The results obtained using thermal imaging diagnostics and pressure sensors were processed statistically, and a possible dependence between them was studied. From the correlation coefficients and P-values obtained, it follows that there is no evident dependence between the monitored values. During resolution of the study other possible partial tasks occurred which would be suitable for supplementing the methodology, its evaluation and making the obtained results more precise.

\section{Acknowledgments}

The presented manuscript was supported by the project Research of New Diagnostic Methods in Invasive Implantology, MŠSR-
3625/2010-11, Stimulus for Research and Development of the Ministry of Education, Science and the project ITMS 26220220185 of the project: Medical University Science Park in Kosice (MediPark) and The Design of Prosthetic and Orthotic Processology in Education, KEGA 031TUKE-4/2013.

\section{References}

[1] LUSARDI, M. M.; NIELSEN, C. C.: Orthotics and Prosthetics in Rehabilitation, 2nd ed., Saunders Elsevier, St. Louis, 2007, ISBN 0-7506-7479-2

[2] Národné centrum zdravotníckych informácií. Činnost' spoločných vyšetrovacích a liečebných zložiek v SR [cit. 07.09.2013]. [online]: <http://www.nczisk.sk/Pages/default. aspx>.

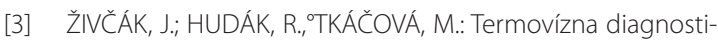
ka, Technická univerzita v Košiciach, 2010, ISBN 978-80-55305333-2

[4] MICHEL, C.C., GILLOTT, H.: Microvascular mechanisms in stasis and ischaemia. In: Bader DL, editor. Pressure sores clinical practice and scientific approach. London: MacMillan Press; 1990. p. 153-63

[5] IVANITSKY, G. R.; KHIZHNYAKA, E. P. and Deeva, A. A.: Biophysical Basis of Medical Thermovision, Biophysics, ISSN 0006-3509, 2012, Vol. 57, No. 1, pp. 106-114

[6] LEE, H.M.; COHEN, M.J.; 2008, Rehabilitation Medicine and Thermography, USA, Morrisville, 2008, ISBN 978-0-61518721-1

[7] KRISTEN, H., LUKESCHITSCH, G., PLATTNER, F., SIGMUND, R, RESCH, P: Thermography as a means for quantitative assessment of stump and phantom pains. Prosthet. Orthot. Int, 1984, 8, 76-81

[8] CUTTI, A.G., PEREGO, P., FUSCA, M.C., SACCHTTI, R., ANDRE$\mathrm{ONI}, \mathrm{G}$. : Assessment of lower limb prosthesis through wearable sensors and thermography, Sensors, ISSN 1424-8220, 2014

[9] HALAJ, M., PALENČÁR, R., CHUDÝ, V., TIMA, J.: Metrological Characteristics of the Tactile Sensor Array. Zborník z konferencie Strojné inžinierstvo 2000, Bratislava, 2000, str. 3-28

[10] TSIOKOS, D., KANELLOS, GT., PAPAIOANNOU, G., PISSADAKIS, S.: Fiber Optic-Based Pressure Sensing Surface for Skin Health Management in Prosthetic and Rehabilitation Interventions, In: Biomedical Engineering - Technical Applications in Medicine, ISBN 978-953-51-0733-0, 432 pages, Publisher: InTech, Chapters published September 06, 2012

[11] ARMSTRONG, D.G.; LAVERY, L.A.; LISWOOD, P.J.; TODD, W.F.; TREDWELL, J.A.: Infrared dermal thermometry for the highrisk diabetic foot, Physical Therapy, 77 (1997), pp. 169-175

[12] DUMBLETON, T.; BUIS, A.W.P.; McFADYEN, A.; McHUGH, B.F.; MCKAY, G.; MURRAY, K.D.; SEXTON, S.: Dynamic interface pressure distibutions of two transtibial prosthetic socket con- 
cepts, Journal of Rehabilitation Research\&Development, Vol. 26, Num. 3, 2009, pp. 405-416

[13] BADER, D. et. al.: (2010) Pressure ulcer Research. Current and Future Perspectives. (eds) Springer Verlag Berlin ISBN-13 978-3-642-06404-3

[14] BAGAVATHIAPPAN, S.; PHILIP, J.; JAYAKUMAR, T.; RAJ, B.; RAO, P.N.S.; VARALAKSHMI, M.; MOHAN, V.: Correlation between plantar foot temperature and diabetic neuropathy by using an infrared thermal imaging technique, Journal of Diabetes Science and Technology, 4 (2010), pp. 1386-1392

[15] BAGAVATHIAPPAN, S.; SARAVANAN, T.; PHILIP, J.; JAYAKUMAR, T.; RAJ, B.; KARUNANITHI, R.; PANICKER, T.; KORATH, M.P.; JAGADEESAN, K.: Infrared thermal imaging for detection of peripheral vascular disorders, Journal of Medical Physics, 34 (2009), pp. 43-47

[16] BHARARA, M.; SCHOESS, J.; ARMSTRONG, D.G.: Coming events cast their shadows before: detecting inflammation in the acute diabetic foot and the foot in remission, Diabetes/Metabolism Research and Reviews, 28 (Suppl.1) (2012), pp. 15-20

[17] BHARARA; M., COBB, J.E. and CLAREMONT, D.J.: Thermography and Thermometry in the Assessment of Diabetic Neuropathic Foot: A Case for Furthering the Role of Thermal Techniques, The International Journal of Lower Extremity Wounds, Vol. 5, No. 4, 250-260 (2006)

[18] BITAR, D.; GOUBAR, A.; DESENCLOS, J.C.: International travels and fever screening during epidemics: a literature review on the effectiveness and potential use of non-contact infrared thermometers, Eurosurveillance, 14 (2009), pp. 1-5

[19] HUDÁK, R., RAJŤÚKOVÁ, V., ŽIVČÁK , J., HUDÁK, J., BEDNARČÍKOVÁ, L.: The use of matrix tactile sensors (MTS) for diagnostics of the efficiency of production, testing and application of a trunk orthosis / - 2012. In: CINTI 2012: 13th IEEE International Symposium on Computational Intelligence and Informatics : proceedings : Budapest, Hungary, November 20-22, 2012. - Budapest: Óbuda University, 2012 P. 299-304. - ISBN 978-1-4673-5204-8

[20] HUDÁK, R.; ŽIVČÁK, J.; ŠARIK, M.; DADEJ, R.; RAŠI, R.: 3D Bioprinters - Future of Implants Biofabrication, Acta Mechanica Slovaca. Roč. 17, č. 1 (2013), s. 52-59. - ISSN 1335-2393

[21] ŽIVČÁK, J.; TREBUŇOVÁ, M.; REPOVSKÝ, A.; LAPUTKOVÁ, G.: Magnetic resonance image artifact due to the examination method and scanning sequences, Acta Mechanica Slovaca. Roč. 17, č. 3 (2013), s. 88-92. - ISSN 1335-2393

[22] MAJERNÍK, J.; ŽIVČÁK, J.: Effect of whole body vibration on functional mobility in elderly patients, Acta Mechanica Slovaca. Roč. 17, č. 3 (2013), s. 64-69. - ISSN 1335-2393

[23] ŽIVČÁK, J.; KELEMENOVÁ, T.; KELEMEN, M.; MAXIM, V.: Modelbased approach to development of engineering systems, Acta Mechanica Slovaca. Roč. 17, č. 3 (2013), s. 56-62. - ISSN
$1335-2393$

[24] TÓTH, T., HUDÁK, R.: Computed tomography - Its development, principle and image artifacts, Acta Mechanica Slovaca. Roč. 17, č. 4 (2013), s. 40-47., ISSN 1335-2393

\section{Biographical notes}

Dr.h.c. prof. Ing. Jozef Živčák, PhD., is a professor of biomedical engineering at the Technical University in Košice. He was born in 1958. He received his MS and PhD degrees from the Technical University of Košice in 1995. Since 2009 he has been a Doctor Honoris Causa of Uzhhorod National University, Ukraine. His research interests include human biomechanics, medical sensors and rehabilitation technology. Today he is head of the Department of Biomedical Engineering and Measurement. Since 1998 he has been an expert witness in machine and electrical technology. He is co-author of more than 280 publications in domestic and foreign journals as well as 9 monographs and 12 books.

doc. Ing. Radovan Hudák, PhD., was born in 1976 in Košice, Slovakia. He received his MS and Ph degrees in biomedical engineering at the Technical University in Košice in 2000 and 2008. Today Mr. Hudák is an associate professor and head of the prosthetics and orthotics study program and vice-head of Department of Biomedical Engineering and Measurement, Technical University of Košice. His research interests include additive manufacturing in medicine, medical thermography, industrial thermography and human biomechanics. Since 2004 he has been the technical assistant at the Centre of Refractive Surgery in Košice. Mr. Hudák has more than 150 publications in domestic and foreign journals. He is co-author of 5 monographs and 10 books.

Ing. Viktória Rajtúková, PhD., was born in 1985 in Lučenec, Slovakia. She received her MS degree in 2011 and her PhD in Biomedical Engineering at the Technical University in Košice in 2014. At present, in the scope of her post-doctoral studies, she is working as a professional scientist on the project "Medical University Science Park in Košice (MediPark)". She is the author of more than 15 professional contributions published in magazines and at conferences. She is the holder of several certificates from the field of prosthetics and orthotics. 